\title{
AGGREGATED FINANCIAL CONTRIBUTIONS OF SOME ACTIVITY SECTORS ON NIGERIA'S ECONOMIC GROWTH USING ARDL MODEL
}

\author{
Amaefula C. $\mathbf{G}^{1}$ \\ ${ }^{1}$ Department of Mathematics and Statistics,Federal University Otuoke, Bayelsa State, Nigeria
}

\author{
Umezurike C. $\mathbf{M}^{2}$ \\ ${ }^{2}$ Department of Banking ana Finance,Federal Polytechnic Kaura Namoda, Zamfara State, \\ Nigeria
}

Article DOI: https://doi.org/10.36713/epra5362

\begin{abstract}
The paper examines the aggregated financial contributions of industrial and services sector output on the economic growth of Nigeria using ARDL model. The data sets on gross domestic product (GDP) and industrial and services sector output (measured in billions of naira) cover the period of 1981 to 2019. The ADF unit root test was used to test the order of integration of the variables under study. Applying Generalized Linear Model (Newton-Raphson) method of estimation, the results showed that both the industrial sector (IND) and services sector (SERV) contributed positively to GDP growth both at the short-run and long-run, significant under 5\% level and the system is adjusting towards long-run equilibrium at the speed of approximately $102 \%$. Therefore, the government should put more effort in industrial and services sector reforms so as to make these sectors more proactive at improving economic growth in Nigeria.
\end{abstract}

KEYWORDS: Industry, services sector, economic growth, ARDL

\section{INTRODUCTION}

It is expected that a nation that is naturally endowed with different mineral resources especially mining and quarrying activities should have proactive economy driven by industrial diversification and services output growth that can boost employment generation and reduce poverty index. According to World Bank Development Indicators (2020), Nigeria is growing slower than its population and large numbers of people are poor. With gross national income per capita of US\$2,100; Nigeria is classified as a lower-middle-income country. It is richly endowed, with relatively young, rural, and multiethnic population, and accounts for the largest economy and population in Africa. However, significant poverty persists despite the government's effort to reduce the high poverty rate. Measured according to the US\$1.90-a-day per capita purchasing power parity poverty line, it is estimated that 42.8 percent of Nigeria's population was living in extreme poverty in 2016. A key development challenge in Nigeria revolves around economic growth, which has had a limited impact on reducing poverty and building shared prosperity.

Nigeria continues its recovery from the 2016 recession, sustaining an estimated 2 percent growth rate in 2019. The crumple of global oil prices during 2014-16, joint with lower domestic oil production, led to a sudden slowdown in economic activity. Nigeria's annual real GDP growth rate, which averaged 7 percent from 2000 to 2014 , fell to 2.7 percent in 2015 and to -1.6 percent in 2016. Growth rebounded to 0.8 percent in $2017,1.9$ percent in 2018 , and then plateau at 2 percent in the first half of 2019, where it is expected to remain for the rest of the year. Services, particularly telecoms, remained the main driver of growth in 2019, although trade started contracting amidst increasing use of policy measures aimed at import substitution. Agricultural growth picked up slightly but remains affected by insurgency in the Northeast region and ongoing farmer-herder conflicts. Industrial performance was 
mixed: growth in the oil sector remained stable, but manufacturing production slowed in a context of weaker power sector supply. Overall, the slow pace of recovery in 2019 is attributable to weak consumer demand and lower public and private investment. The annual headline inflation rate fell from a peak of 15.7 percent in 2016 to a projected 11.6 percent in 2019 but remains high and above the central bank's target of 6-9 percent(Word Bank Group, 2019).

The expectation that industrialization should arouse more economic growth has prompted many economists to formulate theories to encourage industrialization. Famous among the early theories formulated are: Leibenstein's theory of critical minimum effort thesis (Leibensein, 1957). Most of the empirical and theoretical arguments in favour of industrialization has hypothesized that there is a positive correlation between the level of industrialisation and per capita income for developing countries (Bolaky, 2011). There are studies relating to industrialization and economic growth. It has been posited that industrialization through foreign investors can exert a positive effect on economic growth rate (Blomstrom, Lipsey, \& Zegan, 1994). They further argued that the industrialization contribution to the economic growth rate is dependent on the threshold level of income.

The impacts of industry and services sector development on the Nigeria's economic growth have been a recurring issue for analysis over a decade now. Related issues have been investigated both in some developed and developing countries with different findings. According to Obioma et. al(2015), Nigeria has enjoyed a long period of sustained economic growth since 2001 and yet, there is poor contribution from the industrial sector to the country's GDP. The model explain that the influence of industrial output on economic growth is not statistically significant, though the sign obtained from its àpriori expectation is positively related to (economic growth) GDP but does not hold strong enough. Savings has a positive relationship and also significant impact on the economy.

The evidence of a positive, existing causal relationship between the service sector and economic growth is uncertain. Dutt and Lee (1993) use cross country-level data from three decades (the 1960's, 1970's and 1980's) and reveal that any negative or positive effects depends on the measuring techniques for determining the role of the service sector. However, based on the results, the argument arises that the effects are usually negative. Blomstrom (1996) and Liu (2002) and their fellow researchers found mixed results in their studies: Blomstrom suggested a one-way causal relationship with no feedback effects and Liu suggested a bi-directional causality between the variables. Alhowaish(2014) investigated the role of services sector in economic growth of Saudi Arabia during the period of 19692012. Empirical results showed that there exists a long-term stable dynamics equilibrium relationship between the service sector and economic growth. Service industry plays an important role in economic growth since every $1 \%$ increase in service sector output will promote $0.93 \%$ economic growth. Granger causality test shows that two-way Granger causality exists between the service sector and economic growth, services play a clear role in promoting economic growth, and economic growth further promotes the development of service industries.

Despite contradicting results and researchers study dimensions on the subject matter, the present study investigates the contributions industrial and services sector output to GDP growth in Nigeria both in the short-run and long-run relationships. The study also looks at the lapse of time effect of these predictor variables on economic growth of Nigeria. The rest part of the paper is organized s follows; section 2 presents the material and methods, section 3 deals with the data analysis and results, and section 4 presents the conclusion.

\section{MATERIAL AND METHOD}

The method relies on direct observation and experimentation in the acquisition of new knowledge. However, this section provides information on source of data collection, variable measurement and definition, model specifications, estimation and diagnostic test.

\subsection{Source of Data Collection}

The time series data sets on the variables; nominal gross domestic product (GDP), industry (IND) and services (SERV) were obtained from National Bureau of Statistics (published in CBN statistical bulletin, 2020). The data sets (in billions of naira) cover the period of 1981 to 2019 , consisting of 39 observations.

\subsection{Variable Measurement and Definition}

The most commonly measure of economic growth is the GDP, hence, this paper used nominal GDP to measure economic growth, three major consisting indicators of industry sector are; mining and quarrying, manufacturing, electricity/gas and water management/ construction.

The services sector involve the following; trade, accommodation/food services,transportation/storage, information/communication, art/entertainment/recreat ion, finance/insurance, real estate, administration and support services, public administration, education,professional/scientific/technical services, human health and social services and so on. And the variables are defined using first difference of natural logarithm of present and previous values of each variable multiplied by 100 as follows; 
$\nabla \log G D P_{t}=\left(\log G D P_{t}-\log G D P_{t-1}\right) \times 100 \quad, \quad \nabla \log I N D_{t}=\left(\log I N D_{t}-\log I N D_{t-1}\right) \times 100 \quad$ and $\nabla \log S E R V_{t}=\left(\log S E R V_{t}-\log S E R V_{t-1}\right) \times 100$.

\subsection{ARDL model specification}

The linear time series models in which both the explained and the explanatory variables are related not only contemporaneously, but across lagged values as well is known as the ARDL model. It offers the leverage of testing for long-run relationship that is robust irrespective of whether variables of interest are $\mathrm{I}(0), \mathrm{I}(1)$, or mutually co-integrated. The unrestricted model with no trend is of the form;

$\nabla \log G D P_{t}=c_{0}+\sum_{i=1}^{p} c_{1 i} \nabla \log G D P_{t-i}+\sum_{i=1}^{k} c_{2 i} \nabla \log I N D_{t-i}+\sum_{i=1}^{k} c_{3 i} \nabla \log S E R V_{t-i}+c_{1}^{*} E C_{t}$

where $c_{0}$ is the constant term, $c_{1 i}, c_{2 i}$ and $c_{3 i}$ are respectively coefficients associated with differenced $\log$ of lagged GDP, differenced log of lagged regressors (IND and SERV), for $i=1,2 . \cdots, p$ and $i=1,2 . \cdots, k$ respectively. $E C_{t}$ is the error correction term, it measures the co-integrating relationship when $\mathrm{GDP}_{\mathrm{t}}$ and $x_{t}$ 's are cointegrated. Following Pesaran et.al (2001) the appropriate co-integrating relationship for equation (2) above is written as;

$$
E C_{t}=\log G D P_{t}-\sum_{j=1} \frac{\theta_{j}}{\theta_{0}} x_{j, t}
$$

Equation(2) can also be obtained using the regression equation of the form;

$$
\begin{aligned}
& E C_{t}=\log G D P_{t}-\left(c_{0}+\sum_{j=1}^{k} \theta_{j} x_{j, t}\right) \\
& E C_{t}=\log G D P_{t}-\left(c_{0}+c_{1} \log I N D_{t}+c_{2} \log S E R V_{t}\right)
\end{aligned}
$$

The hypothesis $H_{0}: \theta_{0}=\theta_{1}=\theta_{2}=0$ is used to check whether all the variables have long-run relationship by comparing the F-statistic with the Pearson critical value at $5 \%$ level. If the F-statistic is more than upper bound value, we reject $H_{0}$. Alternatively, if the Chi-Square probability value is significant at $5 \%$ level, the variables have long-run relationship. The coefficient $c_{1}^{*}$ in equation (1) measures the speed of adjustment, it is expected to be negative and significant. But if (1) incorporates $E C_{t-1}$ then, the coefficient $c_{1}^{*}$ may take a positive value and $c_{2}^{*}$ is then expected to be negative.

\subsection{Unit Root Test}

The unit root test here, is based on Augmented Dickey Fuller (ADF) test and is of the form

$$
\begin{aligned}
& \nabla y_{t}=\alpha+\alpha_{1} t+\beta y_{t-1}+\sum_{i=1}^{k} \xi_{i} \nabla y_{t-i}+a_{t} \\
& \nabla y_{t}=\alpha+\beta y_{t-1}+\sum_{i=1}^{k} \xi_{i} \nabla y_{t-i}+a_{t} \\
& \nabla y_{t}=\beta y_{t-1}+\sum_{i=1}^{k} \xi_{i} \nabla y_{t-i}+a_{t}
\end{aligned}
$$

where $\mathrm{k}$ is the number of lag variables. In (4) there is intercept term, the drift term and the deterministic trend. The non deterministic trend term removes the trend term as seen in (5) And (6) removes both the constant and deterministic trend term in the above regression. ADF unit root test null hypothesis
$H_{0}: \beta=0$ and alternative $H_{a}: \beta<0$. According to Dickey, and Fuller (1979), if the ADF test statistic is greater than $1 \%, 5 \%$ and $10 \%$ critical values, the null hypothesis of a unit root test is accepted. 
EPRA International Journal of Economic Growth and Environmental Issues- Peer Reviewed Journal

ISSN: 2321-6247

Volume: 8 | Issue: 3 | October 2020 | Journal DOI : 10.36713/epra0713 | SJIF Impact Factor (2020): 8.007

\subsection{Method of Estimation}

The regression models are estimated using Method: Generalized Linear Model (NewtonRaphson / Marquardt steps). Although ARDL models have been used in econometrics for decades, the model has gained popularity in recent years as a method of examining co-integrating relationships between variables through the work of Pesaran and Shin (1998) and Pesaran at al (2001).

\subsection{Model Diagnostic test}

The model diagnostic test here includes stability test using CUSUM test, serial correlation test, heteroscedasticity test and Wald test for coefficient restriction.

\section{DATA ANALYSIS, RESULTS AND DISCUSSION}

This section presents the result of linear multiple regression model of equation (1), the results of the bounds and diagnostic test, result of the specified ARDL model, short-run and long-run test results.

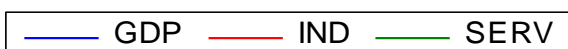

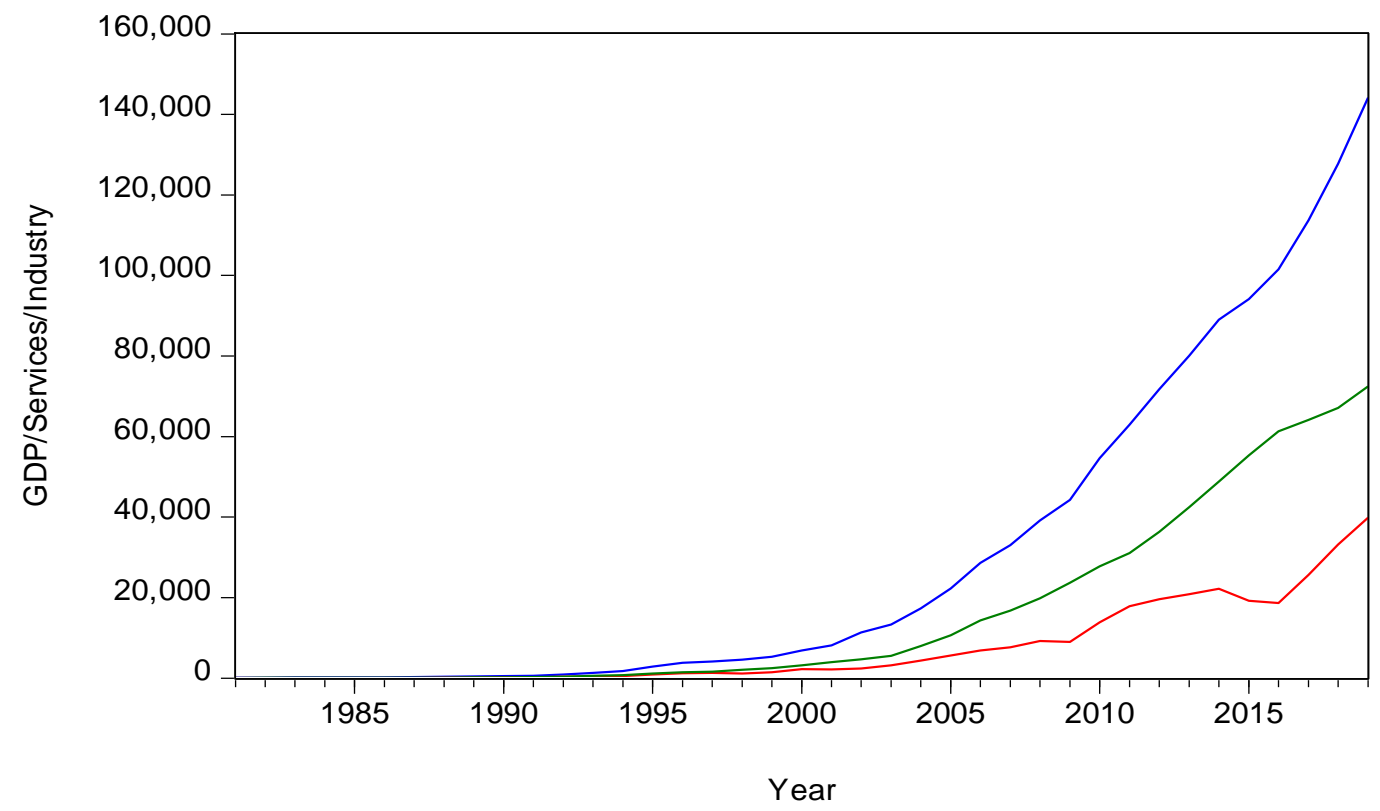

Figure1. Time series plot of GDP, Industry and Services sectors in Nigeria from 1981 - 2019

The three variables under study exhibit upward trend pattern indicating that the variables have increased over the period under investigation.

Table1. ADF unit root test analysis

\begin{tabular}{|c|c|c|c|c|c|}
\hline \multirow[b]{3}{*}{ Variable } & \multirow[b]{3}{*}{$\begin{array}{l}\text { Determinist- } \\
\quad \text { ic Term }\end{array}$} & \multirow[b]{3}{*}{ Lags } & \multirow[b]{3}{*}{$\begin{array}{c}\text { Test } \\
\text { Value }\end{array}$} & & \multirow[b]{3}{*}{ Prob. } \\
\hline & & & & Level & \\
\hline & & & & $\begin{array}{c}1 \% \\
5 \% \\
10 \%\end{array}$ & \\
\hline $\log (G D P)$ & $\mathrm{C}, \mathrm{T}$ & 0 & -0.0285 & $\begin{array}{l}-4.2191 \\
-3.5331 \\
-3.1983\end{array}$ & 0.9943 \\
\hline $\operatorname{Dlog}(\mathrm{GDP})$ & $\mathrm{C}, \mathrm{T}$ & 0 & -3.3445 & $\begin{array}{l}-4.2268 \\
-3.5366 \\
-3.2003\end{array}$ & 0.0749 \\
\hline Log(SERV) & $\mathrm{C}, \mathrm{T}$ & 0 & -0.0867 & $\begin{array}{l}-4.2191 \\
-3.5331 \\
-3.1983\end{array}$ & 0.9933 \\
\hline D Log(SERV) & $\mathrm{C}, \mathrm{T}$ & 0 & -2.7117 & $\begin{array}{l}-4.2268 \\
-3.5366 \\
\end{array}$ & 0.2380 \\
\hline
\end{tabular}


EPRA International Journal of Economic Growth and Environmental Issues- Peer Reviewed Journal

ISSN: 2321-6247

Volume: 8 | Issue: 3 | October 2020 | Journal DOI : 10.36713/epra0713 | SJIF Impact Factor (2020): 8.007

\begin{tabular}{|c|c|c|c|c|c|}
\hline & & & & -3.2003 & \\
\hline DD Log(SERV) & $\mathrm{C}, \mathrm{T}$ & 0 & -7.6417 & $\begin{array}{l}-4.2350 \\
-3.5403 \\
-3.2024\end{array}$ & 0.0000 \\
\hline $\log (I N D)$ & $\mathrm{C}, \mathrm{T}$ & 0 & -1.4720 & $\begin{array}{l}-4.2191 \\
-3.5331 \\
-3.1983\end{array}$ & 0.8218 \\
\hline Dlog(IND) & $\mathrm{C}, \mathrm{T}$ & 0 & -4.3583 & $\begin{array}{l}-4.2350 \\
-3.5403 \\
-3.2024\end{array}$ & 0.0074 \\
\hline
\end{tabular}

The result of Table1 reveals that the logarithm of the variables (gross domestic product, services and industry) are integrated order one (I(1)) and their first logarithm difference are integrated order zero(I(0)) except that of services which indicates that GDP and industry variables are stationary, significant under $10 \%$ and $1 \%$ percent respectively. But the services variable is integrated order zero $\mathrm{I}(0)$ only under second difference.

\subsection{Regression Estimate of the Error Correction (EC)}

The long-run equilibrium relationship of the ARDL model is captured by the error correlation term (EC) and the result is presented below;

$$
E C_{t}=\log \left(G D P_{t}\right)-\left(0.8395+0.4654 \log \left(I N D_{t}\right)+0.5529 \log \left(S E R V_{t}\right)\right)
$$

\subsection{The Result of the Bound test}

The bound test is used to check if there is evidence of long-run relationship amongst the variables.

Table 2. Bound test Analysis

\begin{tabular}{|c|c|c|c|c|c|}
\hline $\begin{array}{c}\text { No. of } \\
\text { lags }\end{array}$ & AIC & SC & $\begin{array}{c}\text { Log } \\
\text { likelihood }\end{array}$ & Serial corr. test & $\begin{array}{c}\text { Wald test for long- } \\
\text { run coefficients }\end{array}$ \\
\hline$(1,5,5)$ & -4.8870 & -4.1541 & 94.1915 & No serial corr. & Significant under1\% \\
\hline$(1,4,4)$ & -4.3270 & -3.6921 & 85.3950 & serial corr. & Significant under1\% \\
\hline$(1,3,3)$ & -4.0839 & -3.5452 & 81.4271 & No serial corr. & Significant under1\% \\
\hline$(1,2,2)$ & -4.1749 & -3.7306 & 83.0616 & No serial corr. & Significant under1\% \\
\hline$(1,1,1)$ & -4.1252 & -3.7733 & 82.2542 & No serial corr. & Significant under1\% \\
\hline$(1,5,4)$ & $-4.9398^{*}$ & $-4.2596^{*}$ & 96.5074 & No serial corr. & Significant under1\% \\
\hline \multicolumn{5}{|c|}{ The symbol '*' indicates the preferred bound. } \\
\hline
\end{tabular}

The result of bound test in Table 2 above indicates that both AIC and SC have lowest values when the ARDL model has $(1,5,4)$ lags; dependent variable(GDP) at $1 \mathrm{lag}$, regressor variable(IND) at 5 lags and regressor variable (SERV) at 4 lags. The likelihood value is also maximum at the chosen model, hence, all the information criteria prefer the standard ARDL model with lag combination $(1,5,4)$ which shows evidence of co-integrating relationship amongst the three variables under study since the Wald test for long-run relationship is significant at $1 \%$ level. The result of the ARDL model as chosen by the information criteria is presented in Table 3 below. 
Table 3. Result of ARDL model

\author{
Dependent Variable: DLOG(GDP) \\ Model: ARDL \\ Method: Generalized Linear Model (Newton-Raphson / Marquardt steps) \\ Sample (adjusted): 19872019 \\ Included observations: 33 after adjustments \\ Family: Normal \\ Link: Identity \\ Dispersion computed using Pearson Chi-Square \\ Convergence achieved after 0 iterations \\ Coefficient covariance computed using observed Hessian
}

\begin{tabular}{lllll}
\hline \hline Variable & Coefficient & Std. Error & z-Statistic & Prob. \\
\hline \hline C & 0.027037 & 0.010935 & 2.472478 & 0.0134 \\
DLOG(GDP(-1)) & 0.048790 & 0.104183 & 0.468308 & 0.6396 \\
DLOG(IND) & 0.524800 & 0.030568 & 17.16808 & 0.0000 \\
DLOG(IND(-1)) & 0.031318 & 0.045997 & 0.680865 & 0.4960 \\
DLOG(IND(-2)) & 0.063784 & 0.024248 & 2.630420 & 0.0085 \\
DLOG(IND(-3)) & 0.055698 & 0.025631 & 2.173080 & 0.0298 \\
DLOG(IND(-4)) & 0.085604 & 0.025351 & 3.376748 & 0.0007 \\
DLOG(IND(-5)) & 0.089454 & 0.020998 & 4.260027 & 0.0000 \\
D(DLOG(SERV)) & 0.416935 & 0.047947 & 8.695771 & 0.0000 \\
D(DLOG(SERV(-1))) & 0.307277 & 0.051978 & 5.911645 & 0.0000 \\
D(DLOG(SERV(-2))) & 0.211626 & 0.057800 & 3.661336 & 0.0003 \\
D(DLOG(SERV(-3))) & 0.158170 & 0.052696 & 3.001525 & 0.0027 \\
D(DLOG(SERV(-4))) & 0.030308 & 0.046008 & 0.658748 & 0.5101 \\
EC & 1.197279 & 0.102366 & 11.69603 & 0.0000 \\
EC(-1) & -1.018021 & 0.099660 & -10.21494 & 0.0000 \\
\hline \hline Mean dependent var & 0.199049 & \multicolumn{2}{c}{ S.D. dependent var } & 0.102308 \\
Sum squared resid & 0.004787 & Log likelihood & 96.50743 \\
Akaike info criterion & -4.939844 & Schwarz criterion & -4.259614 \\
Hannan-Quinn criter. & -4.710967 & Deviance & 0.004787 \\
Deviance statistic & 0.000266 & Restr. Deviance & 0.334944 \\
LR statistic & 1241.506 & Prob(LR statistic) & 0.000000 \\
Pearson SSR & 0.004787 & Pearson statistic & 0.000266 \\
Dispersion & 0.000266 & & & \\
\hline \hline
\end{tabular}

The result in Table3 above shows that the coefficients long-run equilibrium terms EC and EC at lag1 are significant at $1 \%$ level. And the coefficient of EC at lagl is negative and conforms to expectation. The result also indicates that all the regressor variables in their selected lag orders are strictly significant under $5 \%$ level except log changes in the industrial sector (IND) and services sector (SERV) at lag1 and lag4 respectively. Generally, the significant lags in the predictor variables indicate the lapses of time changes in the variables can contribute meaningfully on the GDP growth. 
Date: 08/15/20 Time: 19:58

Sample: 19812019

Included observations: 33

\begin{tabular}{|c|c|c|c|c|c|c|}
\hline Autocorrelation & Partial Correlation & & $\mathrm{AC}$ & PAC & Q-Stat & Prob* \\
\hline .1 .1 & .1 .1 & 1 & -0.023 & -0.023 & 0.0183 & 0.892 \\
\hline .1 .1 & .1 .1 & 2 & -0.062 & -0.062 & 0.1600 & 0.923 \\
\hline .1 .1 & .1 .1 & 3 & -0.023 & -0.026 & 0.1811 & 0.981 \\
\hline$*^{*} . \mid$ & $*^{*}||$. & 4 & -0.156 & -0.162 & 1.1561 & 0.885 \\
\hline .1 .1 & .1 .1 & 5 & 0.003 & -0.009 & 1.1565 & 0.949 \\
\hline$*^{*}||$. & $*^{*}||$. & 6 & -0.117 & -0.144 & 1.7420 & 0.942 \\
\hline$*^{*} .1$ & $*^{* 1 .} \mid$ & 7 & -0.099 & -0.122 & 2.1771 & 0.949 \\
\hline$* \mid$ & $*||$. & 8 & -0.077 & -0.143 & 2.4490 & 0.964 \\
\hline$I^{*}$ &.$\left.\right|^{*}$. & 9 & 0.145 & 0.111 & 3.4646 & 0.943 \\
\hline$*^{*} \mid$ & $*^{*}||$. & 10 & -0.118 & -0.198 & 4.1623 & 0.940 \\
\hline .1 .1 & .1 .1 & 11 & 0.027 & -0.009 & 4.2004 & 0.964 \\
\hline$*^{*}||$. & $*^{* *}|. \quad|$ & 12 & -0.114 & -0.224 & 4.9097 & 0.961 \\
\hline$*||$. & $*^{*} \cdot 1$ & 13 & -0.112 & -0.142 & 5.6380 & 0.958 \\
\hline .1 .1 &.$^{* *}||$. & 14 & -0.041 & -0.250 & 5.7424 & 0.973 \\
\hline .1 .1 & .1 .1 & 15 & 0.065 & 0.001 & 6.0147 & 0.980 \\
\hline$.\left.\right|^{* *} \mid$ & $.\left.\right|^{*} . \mid$ & 16 & 0.286 & 0.155 & 11.571 & 0.773 \\
\hline
\end{tabular}

Fig2. Correlogram of squared residuals for serial correlation test

In Figure2, the p-values of the Q-statistics are not significant, revealing that there is no serial correlation in model residuals, hence, the model is adequate.

Table4. Wald test for Coefficient Restrictions

\begin{tabular}{|c|c|c|c|c|}
\hline $\begin{array}{c}\text { Test } \\
\text { description }\end{array}$ & Null hypothesis & $\begin{array}{c}\text { Chi-Sq. } \\
\text { Stat. }\end{array}$ & df & Prob. \\
\hline $\begin{array}{c}\text { Short-run } \\
\text { relation }\end{array}$ & $H_{0}: c(3)=c(4)=c(5)=c(6)=c(7)=c(8)=0$ & 323.7786 & 6 & 0.0000 \\
\cline { 2 - 5 } & $H_{0}: c(9)=c(10)=c(11)=c(12)=c(13)=0$ & 138.5043 & 5 & 0.0000 \\
\hline $\begin{array}{c}\text { Long-run } \\
\text { relation }\end{array}$ & $H_{0}: c(14)=c(15)=0$ & 147.9402 & 2 & 0.0000 \\
\hline
\end{tabular}

The result of Wald test in Table 4, shows the null hypothesis that the coefficients of short-run effects are all equal to zero is rejected, since the $p$ value of the chi-squared statistic is significant under $1 \%$ level. Hence, there is short-run relationship between the dependent and the explained variables. The null hypothesis that the coefficients of the error correction term (EC) equal to zero is rejected under $5 \%$ level. This explains the existence of long-run relation between the explained variable and the explanatory variables. $E C_{t-1}$ indicates speed of adjustment and it is negative as expected and significant under 5\% level. The result indicates that the system is adjusting towards long-run equilibrium at the speed of approximately $102 \%$.

\subsection{Discussion of Results}

The result of the ARDL model analysis revealed that log changes in industrial sector output has positive impact on log changes in GDP growth at lag 2, 3 and 4 significant under 5\% level. This finding is contrary to Obioma et. al(2015) for Nigeria and Bolaky(2011) argument for developing countries. Also at lag $i(i=0,1,2,3)$ log changes in services sector output exact positive impact on Nigeria's GDP growth, significant under 5\% level.

The coefficients of long-run equilibrium terms EC and EC at lag1 are all significant at 1\% level and the later is negative and conforms to expectation.

The result of Wald test indicates that there is short-run and long-run relationship between the GDP and the predictor variables (industrial and services sector output). The significant long-run relationship between these variables and GDP agrees with that of 
Alhowaish(2014) for Saudi Arabia. The result of long- run relationship reveals that the system is adjusting towards long-run equilibrium at the speed of approximately $102 \%$. The model diagnostic test using Q-statistics reveals that there is no serial correlation in the model residual hence, the model is adequate.

\section{CONCLUSION}

The paper examines the contributions of industrial and services sector output on the economic growth of Nigeria using ARDL model.

The findings indicate that industrial and services sector contribute significantly to economic growth both in the short-run and long-run. The result also reveals that the system is adjusting towards longrun equilibrium at the speed of approximately $102 \%$.

Hence, it becomes very important for the government to make practical effort in industrial and services sector reforms that can heighten Nigeria's economic growth both in the short-run and long-run.

\section{REFERENCES}

1. Abdulkarim Alhowaish(2014). Does Services Sector Cause Economic Growth? Empirical Evidence from Saudi Arabia. The Global study Journal, Vol.7, issue 2, Pp.1-11.

2. Blomstrom, M., Lipsey,R.E. and Zejan, M..(1996). Is fixed investment the key to economic growth? Quarterly Journal of Economics 111, 269-276.

3. Blomstrom, M., Lipsey, R., \& Zegan, M. (1994). What Explains Developing Countries Growth? NBER Working Paper, 4132.

4. Bolaky, B. (2011). The Role of Industrialisation in Economic Development: Theory and Evidence. (p. 52). UNCTAD

5. Dutt, Amitava Krishna and Keun Young Lee (1993). The service sector and economic growth: Some cross-section evidence. International Review of Applied Economics 7 (3):311-29.

6. Dickey, D.A. and W.A. Fuller (1979). "Distribution of the Estimators for Autoregressive Time Series with a unit root,"Journal of the American Statistical Association, 74, 427-431.

7. Leibensein, H. (1957). Economic Backwardness and Economic Growth. New York: Wiley.

8. Liu, X., P. Burridge and P.J.N. Sinclair(2002). Relationship between economic growth, foreign direct investment and trade: Evidence from China. Applied Economics 34, 1433-1440.

9. Obioma B. K, Anyanwu $U$. $N$ and Kalu A.O.U.,(2015), The Effect of Industrial Development on Economic Growth: An Empirical Evidence in Nigeria (1973-2013). European Journal of Business and Management, Vol.7, No.13,

10. Pesaran, M. H. and Shin, Y.,(1998). "An autoregressive distributed-lag modelling approach to cointegration analysis."
Econometric Society Monographs, 31:371-413. http://scholar.google.com/citations? user $=4 w H T$ KPUAAAAJ\&hl=en

11. Pesaran, M. H., Shin, Y., and Smith, R. J.(2001). "Bounds testing approaches to the analysis of level relationships." Journal of Applied Econometrics, 16(3):289-326. https://econpapers.repec.org/RePEc:jae:japmet:v :16:y:2001:i:3:p:289-326

12. World Bank(2020). Nigeria on the Move : A Journey to Inclusive Growth. Systematic Country Diagnostic;. World Bank, Washington, DC. () World Bank. https://openknowledge.worldbank.org/handle/10 986/33347 License: $\quad$ CC $\quad$ BY 3.0 IGO. "http://hdl.handle.net/10986/33347

13. World Bank Group( 2019). Nigeria Economic Update, Fall 2019 : Jumpstarting Inclusive Growth - Unlocking the Productive Potential of Nigeria's People and Resource Endowments. Washington, DC: World Bank. (c) World Bank. https://openknowledge.worldbank.org/handle/10 986/32795 License: CC BY 3.0 IGO.” 